\title{
PENINGKATAN KETERAMPILAN PROSES DAN HASIL BELAJAR MENGGUNAKAN MODEL PROBLEM BASED LEARNING PADA SUB TEMA MERAWAT TUBUHKU SISWA KELAS 1 SD NEGERI 1 GOSONO - WONOSEGORO
}

\author{
Mustamilah \\ mustamilah6@gmail.com \\ SD NEGERI 1 Gosono, Wonosegoro - Boyolali
}

\begin{abstract}
ABSTRAK
Tujuan penelitian ini untuk meningkatkan keterampilan proses pemecahan masalah, hasil belajar matematika siswa kelas 1 SD NEGERI 1 GOSONO dengan menggunakan model Problem Based Learning (PBL) . jenis penelitian yang digunakan dalam penelitian ini adalah penelitian tindakan kelas yang terdiri dari tiga siklus. Masing-masing siklus terdiri atas tahapan perencanaan, pelaksanaan tindakan, observasi dan refleksi. Instrumen pengumpulan data menggunakan rubrik penilaian keterampilan proses pemecahan masalah, dan soal tes Tema 1 Sub Tema 3 tentang merawat tubuh. Analisis data dilakukan dengan menggunakan analisis deskriptif komparatif yaitu membandingkan kondisi awal sebelum tindakan, hasil siklus 1, siklus 2, dan siklus 3. Hasil penelitian menunjukkan bahwa model PBL dapat : a) meningkatkan keterampilan proses pemecahan masalah Tema 1 Sub Tema 3 tentang merawat tubuh siswa kelas 1 SD NEGERI 1 GOSONO. Presentase kenaikan keterampilan pemecahan masalah sebesar $9,09 \%$ untuk siklus $1,11,36 \%$ untuk siklus $2,13,63 \%$ untuk siklus 3 . b) meningkatkan presentase jumlah siswa yang mencapai ketuntasan belajar minimal (KKM) pada Bahasa Indonesia sebagai berikut : pada kondisi awal presentase pencapaian KKM sebesar 22,7\% (5 siswa), pada siklus 1 presentase meningkat menjadi 40,9\%(9 siswa), pada siklus 2 presentase meningkat menjadi 59,09\%(13 siswa), pada siklus 3 presentase meningkat menjadi $72,72 \%$ (16 siswa). Sedangkan untuk Matematika pada kondisi awal presentase pencapaian KKM sebesar $36,36 \%$ ( 8 siswa), pada siklus 1 presentase meningkat menjadi $36,36 \%$ (8 siswa), pada siklus 2 presentase meningkat menjadi 63,63\%(14 siswa), pada siklus 3 presentase meningkat menjadi 77,27\%(17 siswa).

Kata kunci : Pembelajaran Tematik Integratif, hasil belajar, model pembelajaran $P B L$, Pendekatan Pembelajaran Saintifik

\section{PENDAHULUAN}

Pendidikan merupakan proses dimana seseorang dihadapkan pada pengaruh lingkungan yang terpilih dan terkontrol (khususnya lingkungan sekolah) sehingga ia dapat memperoleh perkembangan kemampuan sosial dan kemampuan individu yang optimum. Pendidikan tak lepas dari perkembangan kurikulum,
\end{abstract}


kurikulum 2013 pembelajaran yang digunakan adalah tematik terpadu. Dalam pembelajaran tematik terpadu siswa dituntut berperan aktif dalam pembelajran. Namun kenyataannya di SD N 1 Gosono masih menggunakan model pembelajaran yang konvensional dan cenderung membosankan dan anak tidak bisa mengembangkan keterampilan yang dia miliki. Hal ini berdampak pada kurangnya siswa dalam keterampilan proses dan hasil belajar di SD N 1 Gosono. kemampuan siswa dalam keterampilan proses terutama dalam mengamati, menanya, mencoba, mengolah, menyaji, menalar, mencipta, menyajikan, dan mengkomunikasikan sangat rendah. Selain itu, dari hasil belajar prosentase ketuntasan belajar yeng mencapai KKM juga masih rendah kurang dari 50\%.

Upaya yang harus dilakukan untuk meningkatkan hasil belajar salah satunya adalah menyelaraskan kegiatan pembelajaran dengan nuansa kurikulum yang menekankan pada dimensi pedagogik modern dalam pembelajaran yaitu menggunakan Pendekatan Ilmiah. Sehingga dalam kurikulum 2013 ini siswa terlibat secara aktif dalam pembelajaran. Dari berbagai alasan penulis memuruskan untuk membuat Penelitian Tindakan Kelas (PTK). Model Pembelajaran yang dipilih oleh peneliti adalah Problem Based Learning (PBL).

Dalam rangka mengatasi masalah tersebut, maka penulis berusaha menerapkan suatu model pembelajaran yang inovatif untuk meningkatkan keaktifan siswa dalam proses pembelajaran yang berlangsung, sehingga keterampilan proses dan hasil belajar yang dicapai meningkat. Salah satu alternatif yang dipakai adalah dengan menggunakan model dan media yang cocok sesuai karakteristik siswa, yaitu menggunakan model pembelajaran $P B L$.

\section{KAJIAN PUSTAKA}

Pembelajaran tematik terpadu berfungsi untuk memberikan kemudahan bagi peserta didik dalam memahami dan mendalami konsep materi yang tergabung dalam tema serta dapat menambah semangat belajar karena materi yang dipelajari merupakan materi yang nyata (kontekstual) dan bermakna bagi peserta didik.dalam pembelajaran tematik, tema berperansebagai pemersatu kegiataqan pembelajaran dengan memadukan beberapa pelajaran sekaligus. Adapun muatan pelajaran yang dikembangkan adalah muatan PPKn, Bahasa Indonesia, IPA, IPS, Matematika, Seni Budaya, dan Prakarya, serta Jasmani, Olahraga dan Kesehatan. Ciri-ciri Pembelajaran Tematik Terpadu:

a. Berpusat pada anak.

b. Memberikan pengalaman langsung pada anak.

c. Pemisahan antarmuatan pelajaran tidak begitu jelas (menyatu dalam satu pemahaman dalam kegiatan). 
d. Menyajikan konsep dari berbagai pelajaran dalam satu proses pembelajaran (saling terkait antarmuatanpelajaran yang satu dengan lainnya).

e. Bersifat luwes (keterpaduan berbagai muatanpelajaran).

f. Hasil pembelajaran dapat berkembang sesuai dengan minat dan kebutuhan anak (melalui penilaian proses dan hasil belajarnya

\section{Model Pembelajaran Problem Based Learning (PBL)}

PBL merupakan model pembelajaran yang berorientasi pada pembelajaran konstruktivisme. Teori konstruktivis ini penting dalam psikologi pendidikan yaitu dalam hal ini guru tidak hanya sekedar memberikan pengetahuan kepada siswa, tetapi siswa harus membangun sendiri pengetahuan dalam benaknya. Menurut Schmidt (1993); Savery dan Duffy (1995); Hendry dan Murphy (1995) dalam Rusman (2012: 231), dari segi paedagogis, PBL didasarkan pada teori belajar konstruktivisme bahwa untuk memecahkan suatu masalah perlu adanya interaksi antara pengalaman siswa dengan kenyataan yang terjadi saat ini. Pemecahan masalah tersebut perlu melewati beberapa tahap untuk dicari solusi pemecahan masalah yang terbaik

Karakteristik PBL menurut Rusman (2012: 232), karakteristik PBL berorientasi pada permasalahan yang menjadi titik awal dalam pembelajaran. Permasalahan yang diangkat merupakan permasalahan yang ada di lingkungan siswa untuk kemudian dipecahkan berdasarkan pengetahuan serta pengalaman siswa yang didukung oleh fakta yang ada. Permasalahan tersebut menantang pengetahuan, sikap, dan kompetensi yang dimilki oleh siswa. Bagaimana siswa berusaha menyelesaikan masalah berdasarkan ketiga hal yang dimiliki masingmasing siswa tersebut untuk kemudian disatukan pemikirannya dan dipecahkan secara berkelompok. Dalam prosesnya, pemecahan masalah melibatkan berbagai sumber belajar yang nantinya diakhiri dengan evaluasi dari informasi yang sudah didapat dari berbagai sumber belajar tersebut agar diperoleh solusi pemecahan masalah yang paling tepat.

Berdasarkan hakekat pembelajaran tematik terpadu, maka model pembelajaran $P B L$ dapat dijadikan alternatif model pembelajaran tema 1 subtema 3 di SD. Implementasi model pembelajaran $P B L$, secara teoritik dapat meningkatkan hasil keterampilan proses dan hasil belajar tema 1 subtema 3.

Berbagai penelitian tindakan membuktikan potensi PBL tersebut secara empirik. Hasil penelitian dari Linda Rachmawati pada tahun 2011, Universitas Negeri Malang dengan judul "Penerapan Model Problem Based Learning (PBL) untuk Meningkatkan Pembelajaran IPA Siswa Kelas V SD Negeri Pringapus 2 Kecamatan Dongko Kabupaten Trenggalek". Hasil penelitian menunjukkan bahwa penggunaan model pembelajaran $P B L$ dapat dilaksanakan sesuai harapan 
peneliti. Hal ini ditunjukkan dengan adanya peningkatan keberhasilan guru dalam penerapan model PBL dari 76,65 pada siklus I menjadi 93,3 pada siklus II. Aktivitas siswa meningkat dari $58,6 \%$ pada siklus I menjadi $71,4 \%$ pada siklus II.Hasil belajar juga meningkat dari rata-rata 63,4 pada siklus I menjadi 80,94 pada siklus II. Simpulan penelitian menyatakan bahwa penerapan model PBL dapat meningkatkan hasil belajar dan aktivitas siswa di SD Negeri Pringapus 2.

Hasil penelitian dari Ebti Lusiana Dumgair dengan judul "Penerapan Model Problem Based Learning (PBL) untuk Meningkatkan Pembelajaran IPA pada Siswa Kelas V SDN Madyopuro 3 Kecamatan Kedungkandang Kota Malang". Hasil penelitian menunjukkan bahwa penggunaan model pembelajaran PBL dapat dilaksanakan sesuai harapan peneliti. Hasil ini terlihat dari meningkatnya aktivitas belajar siswa dari siklus I ke siklus II. Peningkatan itu dalam aspek mengemukakan konsep daur air, mengemukakan pertanyaan, menjawab pertanyaan, memecahkan masalah dengan tepat, mengemukakan ide, dan membuat laporan sederhana tentang langkah-langkah agar daur air tidak terganggu. Rata-rata skor aktivitas siswa meningkat dari $65,8 \%$ pada siklus I menjadi $96,93 \%$ pada siklus II.

Selain itu model $P B L$ dapat menunjang kemampuan siswa dalam menyampaikan hasil diskusi di depan kelas. Berdasarkan penelitian terdahulu, meskipun menggunakan model yang sama yaitu PBL, namun materi yang dikaji tidak sama atau bukan materi perubahan lingkungan. Selain itu, belum semua penelitian terdahulu menyoroti tentang performansi guru. Padahal performansi guru amatlah penting karena akan berpengaruh terhadap aktivitas dan hasil belajar siswa

\section{PENDEKATAN PEMBELAJARAN SAINTIFIK}

\section{Hakikat Pendekatan Pembelajaran Saintifik}

M. Hosnan (2014:34) mengemukakan bahwa implemntasi kurikulum 2013 dalam pembelajaran dengan pendekatan saintifik adalah proses pembelajaran yang dirancang sedemikian rupa agar peserta didik secara aktif mengonstruksikan konsep, hukum atau prinsip melalui tahapan-tahapan menagamati, merumuskan masalah, mengajukan atau merumuskan hipotesis, mengumpulkan data dengan berbagai tehnik, menganalisis data, menarik kesimpulan dan mengkimunikasikan konsep, hukum atau prinsip yang “ ditemukan".Kondisi pembelajaran yang diharapkan dari pendekatan saintifik adalah mendorong peserta didik dalam mencari tahu dari berbagai sumber melalui observasi, bukan hanya diberi tahu. 


\section{Hasil Belajar}

Hasil belajar merupakan perubahan perilaku yang diperoleh siswa setelah mengalami kegiatan pembelajaran. Perolehan aspek-aspek perubahan perilaku tersebut tergantung pada apa yang dipelajari oleh siswa. Sudjana (2010: 22) bahwa "hasil belajar adalah kemampuan-kemampuan yang dimiliki siswa setelah ia menerima pengalaman belajarnya". Suprijono (2010: 7) bahwa "hasil belajar adalah perubahan perilaku secara keseluruhan, bukan hanya salah satu aspek potensi kemanusiaan saja". Rifa'i dan Anni (2009: 85) berpendapat bahwa "hasil belajar merupakan perubahan perilaku yang diperoleh peserta didik setelah mengalami kegiatan belajar". Rifa'I dan Anni (2009: 85) berpendapat bahwa hasil belajar baru dapat diperoleh setelah peserta didik mengalami aktivitas belajar. Peserta didik yang mengalami aktivitas belajar mengenai sebuah konsep akan menuai penguasaan konsep sebagai hasil dari belajar peserta didik. Hasil belajar menurut Bloom (1956) dalam Rifa'i dan Anni (2009: 86-90) dibedakan menjadi tiga taksonomi yang disebut dengan ranah belajar. Ranah belajar terdiri dari ranah kognitif (cognitive domain), ranah afektif (affective domain), dan ranah psikomotorik (psychomotoric domain). Berdasarkan uraian diatas tujuan pembelajaran $P B L$ akan tercapai. Tujuan tersebut adalah meningkatnya kompetensi keterampilan proses pemecahan masalah pada tema 1 sub tema 3 tentang merawat tubuh dan peningkatan penguasaan konsep-konsep hasil belajar tentang merawat tubuh.

\section{METODE PENELITIAN}

Penelitian ini dilaksanakan di SDN 1 Gosono pada kelas 1 Tema 1 semester 1 Tahun Pelajaran 2014/2015. Penelitian ini diawali dengan pembuatan proposal pada bulan Juli 2014. Dilanjutkan pada bulan September 2014. Siklus pertama dilakukan pada tanggal 1 September 2014 sedangkan siklus kedua dilaksanakan pada tanggal 10 September 2014. Subyek penelitian ini siswa kelas 1 SDN 1 Gosono yang berjumlah 22 anak. Yang terdiri dari 15 siswa laki-laki dan 7 siswa perempuan. Sumber data berasal dari sumber data primer dan data sekunder. Sumber data primer diperoleh dari hasil belajar dan skor keterampilan proses. Sedangkan sumber data sekunder diperoleh dari tingkat aktivitas siswa dan tingkat aktivitas guru dalam pembelajaran.

Teknik pengumpulan data pada penelitian ini menggunakan teknik tes dan non tes. Teknik tes digunakan untuk memperoleh hasil belajar pada Tema 1 . Sedangkan teknik non tes digunakan untuk memperoleh data tentang keterampilan proses. Kisi-kisi instrument hasil belajar mencakup 10 item. 5 item untuk muatan matapelajaran Bahasa Indonesia dan 5 item untuk muatan matapelajaran Matematika. Sedangkan instrument keterampilan proses berjumlah 10 indikator. 
Analisis data digunakan untuk mengukur instrument yang valid. Valid berarti instrumen tersebut dapat digunakan untuk mengukur apa saja yang akan diukur.

Teknik yang digunakan untuk menguji kevalidan data menggunakan teknik corrected item to total correlation yang dinotasikan (r). suatu item dianggap jika memiliki corrected item total correlation yang dinotasikan ( $\mathrm{r}) \geq 0,3$ (Sugiyono,2008). Sedangkan hasil dari instrumen keterampilan proses dari 7 item menunjukkan bahwa corrected item to tal correlation $\geq 0,3$. Ini menunjukkan bahwa instrument yang digunakan sudah valid. Data yang berupa hasil pengamatan atau observasi diklasifikasikan sebagai data kualitatif. data hasil tes dianalisis secara deskriptif komparatif yaitu dengan membandingkan hasil tes antar siklus. Obyek analisisnya adalah hasil tes sebelum dan sesudah mengalami tindakan tergantung berapa banyaknya siklusnya. Selanjutnya data hasil tes antar siklus dibandingkan sehingga dapat mencapai ketuntasan yang diharapkan.

Tolok ukur dalam keberhasilan dalam penelitian ini dapat diukur dengan indikator sebagai berikut : 1) presentase jumlah siswa yang mencapai KKM 50 \%, 2) meningkatnya keterampilan proses pemecahan masalah sebesar $15 \%$ pada siklusnya. Prosedur PTK ini terdiri dari empat tahapan yang saling terkait dan berkesinambungan yaitu perencanaan (planning), tindakan (action), obervasi (observe) dan refleksi (reflect).(Ditjen Dikti, 1999:25)

\section{HASIL PENELITIAN DAN PEMBAHASAN}

\section{Dekripsi Hasil Tiap Siklus Dan Antar Siklus}

Setelah melakukan analisa terhadap 3 siklus yang dilaksanakan, maka dapat disimpulkan bahwa penggunaan model pembelajaran $P B L$ materi tema 1 sub tema 3 merawat tubuh menunjukkan peningkatan keterampilan proses dan hasil belajar siswa. Tabel 1 merangkum komparasi tingkat hasil belajar dari kondisi awal, siklus 1, siklus 2, dan siklus 3, pada muatan matapelajaran Bahasa Indonesia.

Tabel 1. Komparasi hasil belajar mapel Bahasa Indonesia

\begin{tabular}{|l|l|l|}
\hline Pembelajaran & Mean & \% Ketuntasan \\
\hline Kondisi awal & 60,5 & 36,6 \\
\hline Siklus 1 & 62,95 & 50 \\
\hline Siklus 2 & 64,72 & 59,09 \\
\hline Siklus 3 & 80,63 & 90,90 \\
\hline
\end{tabular}

Dari tabel 1 dan 2 diperoleh data sebagia berikut : a) pada kondisi awal, mean hasil belajar Mapel Bahasa Indonesia mencapai 60,5 (36,6\% mencapai KKM), 
sedangkan mean untuk Mapel Matematika 59,55 (22,72 mencapai KKM); 2) pada siklus 1 mean hasil belajar Mapel Bahasa Indonesia menjadi 62,95dan presentase meningkat menjadi 50\%.

Tabel 2. Komparasi hasil belajar mapel Matematika

\begin{tabular}{|l|l|l|}
\hline Pembelajaran & Mean & \% Ketuntasan \\
\hline Kondisi awal & 59,55 & 22,72 \\
\hline Siklus 1 & 58,5 & 36,36 \\
\hline Siklus 2 & 66,72 & 68,18 \\
\hline Siklus 3 & 80,72 & 90,90 \\
\hline
\end{tabular}

Sedangkan mean untuk muatan mapel Matematika menjadi 58,5 dan presentase menjadi 36,36\%;3) pada siklus 2 mean hasil belajar Mapel Bahasa Indonesia menjadi 64,72 dan presentase meningkat menjadi 59,09\%. Sedangkan mean untuk Mapel Matematika menjadi 66,72 dan presentase menjadi 68,17\%;4) pada siklus 3 mean hasil belajar Mapel Bahasa Indonesia menjadi 80,63 dan presentase meningkat menjadi $90,90 \%$.

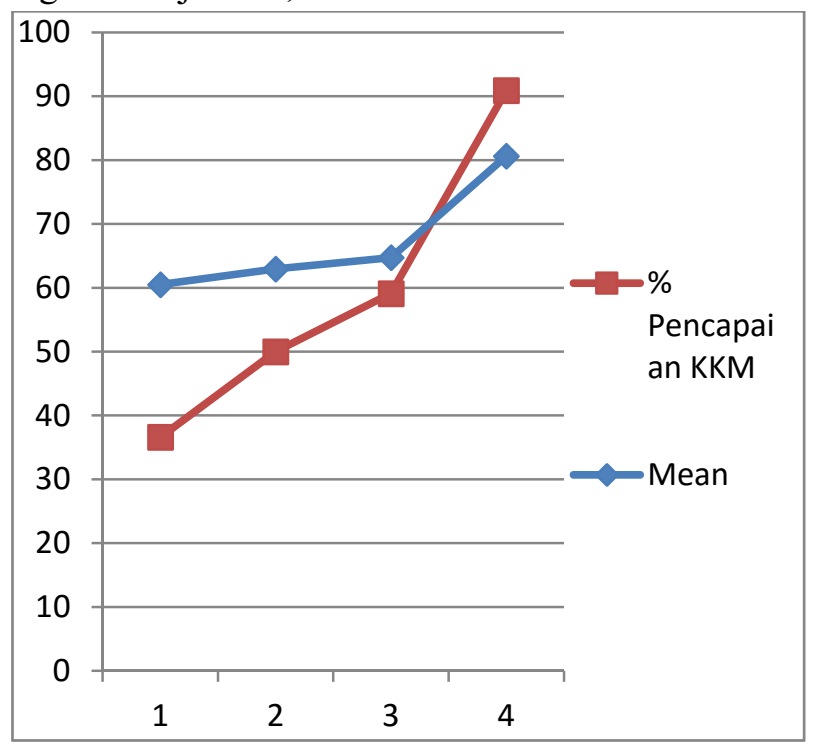

Grafik 1. Mean dan Ketuntasan hasil belajar siswa pada muatan mapel Bahasa Indonesia

Sedangkan mean untuk muatan mapel Matematika menjadi 80,72 dan persentase menjadi $90,90 \%$. Secara visual, capaian hasil belajar dan persentase keuntasan belajar dapat dicermati pada grafik 1 dan 2 . 
Scholaria, Vol. 5, No. 1, Januari 2015:92 -102

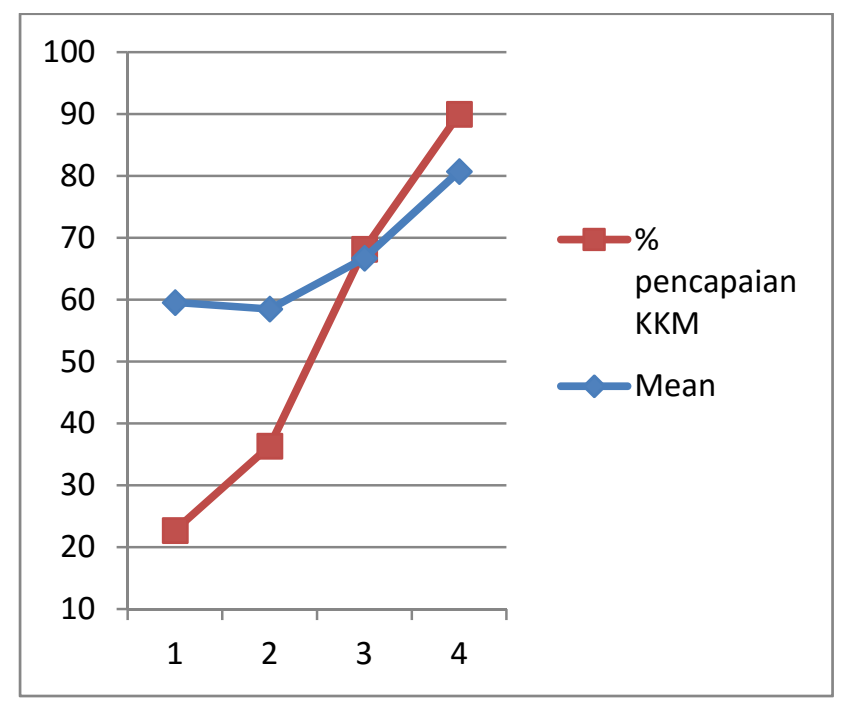

Grafik 2. Mean dan Ketuntasan hasil belajar siswa pada muatan mapel Matematika

\section{Temuan Penelitian dan Pembahasan}

Dari tabel 4.17 keterampilan proses kondisi awal, siklus 1, siklus 2 dan siklus 3 menunjukkan temuan rerata keterampilan proses pada kondisi pada kondisi awal proses hanya mencapai 18,27; pada siklus 1 rata-rata keterampilan proses mencapai 20,3. Capaian ini menunjukkan peningkatan keterampilan proses sebesar 9,09\%. Pada siklus 2 rata-rata keterampilan proses mencapai 22,40. Capaian ini menunjukkan peningkatan keterampilan proses sebesar 11,36\%. Siklus 3 rata-rata keterampilan proses mencapai 24,77. Capaian ini menunjukkan peningkatan keterampilan proses sebesar 13,63\%.

Ini bermakna siswa mampu mengamati, mengukur, melaksanakan penelitian, mengumpulkan, menganalisis, dan mempresentasikan data. Temuan ini sejalan dengan penelitian Sugiyanto (2012) dan Rutinah (2013).

Data grafik 4.4 dan 4.5 hasil belajar siswa kondisi awal,siklus 1, siklus 2, dan siklus 3 menunjukkan temuan kondisi awal pada mapel Bahasa Indonesia, mean 60,5, pada siklus 1 mean 64,72, pada siklus 2 mean 62,95, pada siklus 3 mean 80,63 . Temuan ini mengindikasikan adanya peningkatan hasil belajar siswa pada mapel Bahasa Indonesia. Besarnya peningkatan 50\% untuk siklus 1, 59,09\% siklus 2, 90,90\% siklus 3. Pada mapel Matematika , mean 59,55, pada siklus 1 mean 58,5, pada siklus 2 mean 66,72, pada siklus 3 mean 80,72. Temuan ini mengindikasikan adanya peningkatan hasil belajar siswa pada mapel Matematika. Besarnya peningkatan $36,36 \%$ untuk siklus1, 68,68\% siklus 2, 90,90\% siklus3. 
Dari keduan temuan tersebut jika dibandingkan dengan indikator kinerja 50\% ternyata temuan siklus 1 , siklus 2 dan siklus 3 telah mencapai keberhasilan.

\section{TEMUAN PENELITIAN DAN PEMBAHASAN}

\section{Keberhasilan model $P B L$ dalam meningkatkan keterampilan siswa}

Dari tabel keterampilan proses kondisi awal, siklus 1, siklus 2 dan siklus 3 menunjukkan temuan rerata keterampilan proses pada kondisi pada kondisi awal proses hanya mencapai 18,27 ; pada siklus 1 rata-rata keterampilan proses mencapai 20,3. Capaian ini menunjukkan peningkatan keterampilan proses sebesar 9,09\%. Pada siklus 2 rata-rata keterampilan proses mencapai 22,40. Capaian ini menunjukkan peningkatan keterampilan proses sebesar $11,36 \%$. Siklus 3 rata-rata keterampilan proses mencapai 24,77. Capaian ini menunjukkan peningkatan keterampilan proses sebesar 13,63\%. Ini bermakna siswa mampu mengamati, mengukur, melaksanakan penelitian, mengumpulkan, menganalisis, dan mempresentasikan data. Temuan ini sejalan dengan penelitian Sugiyanto (2012) dan Rutinah (2013).

\section{Keberhasilan model PBL dalam meningkatkan hasil belajar siswa}

Data grafik 4.4 dan 4.5 hasil belajar siswa kondisi awal,siklus 1, siklus 2, dan siklus 3 menunjukkan temuan kondisi awal pada mapel Bahasa Indonesia, mean 60,5, pada siklus 1 mean 64,72, pada siklus 2 mean 62,95, pada siklus 3 mean 80,63 . Temuan ini mengindikasikan adanya peningkatan hasil belajar siswa pada mapel Bahasa Indonesia. Besarnya peningkatan 50\% untuk siklus1, $59,09 \%$ siklus 2, 90,90\% siklus 3. Pada mapel Matematika, mean 59,55, pada siklus 1 mean 58,5, pada siklus 2 mean 66,72, pada siklus 3 mean 80,72. Temuan ini mengindikasikan adanya peningkatan hasil belajar siswa pada mapel Matematika. Besarnya peningkatan 36,36\% untuk siklus1, 68,68\% siklus 2, 90,90\% siklus3. Dari keduan temuan tersebut jika dibandingkan dengan indikator kinerja 50\% ternyata temuan siklus 1, siklus 2 dan siklus 3 telah mencapai keberhasilan.

Keampuhan model $P B L$ mampu meningkatkan keterampilan proses dan hasil belajar siswa. Keampuhan ini terbukti ddalam sintak pembelajaran; 1) sintak pertama merencanakan tugas terbukti siswa mampu mengamati. 2) sintak kedua melakukan investigasi terbukti siswa mampu mengklasifikasikan, memprediksi, melaksanakan pengamatan dan mengumpulkan data. 3) sintak ketiga menyiapkan laporan terbukti siswa mampu menuliskan laporan dari pengamatan. 4) sintak keempat presentasi siswa terbukti mampu mempresentasikan hasil didepan kelas. 5) sintak kelima evaluasi terbukti siswa 
mampu memberikan masukan kepada hasil presentasi kelompok lain. Temuan ini sejalan dengan penelitian Sugiyanto (2012) dan Rutinah (2013).

\section{PENUTUP}

\section{Simpulan}

Berdasarkan hasil penelitian dan pembahasan dapat disimpilkan bahwa model pembelajaran PBL dapat: 1) meningkatkan keterampilan proses pada pembelajaran tematik siswa SD kelas 1 SDN 1 Gosono, kecamatan Wonosegoro, Kabupaten Boyolali; 2) meningkatkan hasil belajar pada pembelajaran tematik siswa SD kelas 1 SDN 1 Gosono, kecamatan Wonosegoro, Kabupaten Boyolali

\section{Saran}

Saran yang peneliti sampaikan dalam penelitian ini, adalah para guru hendaknya: Menggunakan model pembelajaran PBL dalam pembelajaran; melatih siswa untuk berpartisipasi aktif dalam pembelajaran dikelas; dan mengembangkan keterampilan proses pemecahan masalah.

\section{DAFTAR PUTAKA}

Amir, M. Taufiq. 2010. Inovasi Pendidikan melalui Problem Based Learning Bagaimana Pendidik Memberdayakan Pemelajar di Era Pengetahuan. Jakarta: Kencana.

Dumgair, Ebti Lusiana. 2007. Penerapan Model Problem Based Learning (PBL) untuk Meningkatkan Pembelajaran IPA pada Siswa Kelas V SDN Madyopuro 3 Kecamatan Kedungkandang Kota Malang. Skripsi Universitas Negeri Malang.

Hosnan..2014. Pendekatan Saintifik dan Kontekstual dalam Pembelajaran Abad 21. Jakarta: Ghalia Indonesia

Kemendikbud. 2014. Materi Pelatihan Guru Implementasi Kurikulum 2013 Tahun 2014. Jakarta : Badan Pengembangan Sumber daya Manusia Pendidikan dan Kebudayaan dan Penjamin Mutu Pendidikan.Jakarta: Kementrian Pendidikan dan Kebudayaan.

Rachmawati, Linda. 2011. Penerapan Model Problem Based Learning (PBL)

untuk Meningkatkan Pembelajaran IPA Siswa Kelas V SD Negeri Pringapus 2 Kecamatan Dongko Kabupaten Trenggalek. Skripsi Universitas Negeri Malang.Rifa'i, Achmad dan Catharina Tri Anni. 2009. Psikologi Pendidikan. Semarang:Universitas Negeri Semarang Press. 
Rusman. 2012. Model-model Pembelajaran Mengembangkan Profesionalisme Guru. Jakarta: Raja Grafindo Persada.

Sahin, Mehmet and Yorek Nurettin. 2009. A comparison of problem-based learning and traditional lecture students' expectations and course grades in an introductory physics classroom: Academic Journals. Scientific Research and Essay Vol.4 (8), pp. 753-762

Selcuk, Gamze Sezgin. 2010. The effects of problem-based learning on preservice teachers' achievement, approaches and attitudes towards learning physics: Academic Journals. International Journal of the Physical Sciences Vol. 5(6), pp. 711-723

Sudjana, Nana. 2010. Penilaian Hasil Proses Belajar Mengajar. Bandung: PT. Remaja Rosdakarya.

Suprijono, Agus. 2010. Cooperative Learning Teori dan Apikasi PAIKEM. Yogyakarta: Pustaka Pelajar.

Trianto. 2012. Mendesain Model Pembelajaran Inovatif-Progresif Konsep, Landasan, dan Implementasinya pada Kurikulum Tingkat Satuan Pendidikan (KTSP). Jakarta: Kencana.

Wena, Made. 2010. Strategi Pembelajaran Inovatif Kontemporer Suatu Tinjauan Konseptual Operasional. Jakarta: Bumi Aksara. 